\title{
The effect of biostymulants and stubble crop on weed infestation of short-term spring wheat monoculture
}

\section{Wpływ stosowania biostymulatorów i międzyplonu ścierniskowego na zachwaszczenie łanu krótkotrwałej monokultury pszenicy jarej}

\author{
Adela Maziarek $^{1 *}$, Danuta Parylak ${ }^{2}$, Roman Wacławowicz ${ }^{2}$
}

\section{Summary}

The field research was conducted at the Agricultural Advisory Centre in Łosiów in 2011 and 2012. The aim of the study was to investigate the response of spring wheat on continuous cropping and to determine the impact of regeneration treatments (biostimulants, stubble crop) on weed infestation and the yield of wheat grown in monoculture. The use of biostimulants in monoculture proved to be ineffective in reducing weed infestation of spring wheat and stubble cropping caused a decrease only in dry matter of weeds. There was no unequivocal effect of the experimental factors on the yield of spring wheat.

Key words: spring wheat; monoculture; stubble crop; biostimulants; weed; yield

\section{Streszczenie}

Badania przeprowadzono w latach 2011 i 2012 na terenie Opolskiego Ośrodka Doradztwa Rolniczego w Łosiowie. Celem doświadczeń było poznanie reakcji pszenicy jarej na uprawę w monokulturze oraz określenie wpływu zabiegów regeneracyjnych (biostymulatory, międzyplon ścierniskowy) na zachwaszczenie i wielkość plonu pszenicy uprawianej po sobie. Stosowanie biostymulatorów w monokulturze okazało się nieskuteczne w redukcji zachwaszczenia łanu pszenicy jarej, a przyorywanie międzyplonu ścierniskowego sprzyjało jedynie ograniczeniu powietrznie suchej masy chwastów. Nie stwierdzono jednoznacznego wpływu czynników doświadczenia na plonowanie roślin.

Słowa kluczowe: pszenica jara; monokultura; międzyplon ścierniskowy; biostymulatory; zachwaszczenie; plon

\footnotetext{
1 Opolski Ośrodek Doradztwa Rolniczego w Łosiowie

Główna 1, 49-330 Łosiów

${ }^{2}$ Uniwersytet Przyrodniczy we Wrocławiu

PI. Grunwaldzki 24A, 50-363 Wrocław

*corresponding author: adela.maziarek@oodr.pl
} 


\section{Wstęp / Introduction}

Częsta uprawa zbóż po sobie sprzyja zachwaszczeniu łanu oraz kompensacji niektórych gatunków chwastów (Głowacka 2006). To zjawisko szczególnie intensywnie przebiega w pierwszych latach trwania monokultury, a jego efektem jest często spadek plonowania (Parylak 1998; Jaskulski i wsp. 2000).

Pszenica wykazuje szczególną wrażliwość na zachwaszczenie, zwłaszcza we wczesnych fazach rozwojowych (Haliniarz 2010). Jednym ze sposobów ograniczenia zachwaszczenia jest zwiększenie konkurencyjności rośliny uprawnej względem chwastów przez stosowanie zabiegów regeneracyjnych (Parylak 1997; Wojciechowski 1998; Gawęda 2009).

Dla środowiska przyjaznym sposobem wzmocnienia kondycji rośliny uprawnej, a przez to pośrednio ograniczenia zachwaszczenia łanu, jest uprawa międzyplonów ścierniskowych (Teasdale i wsp. 1991; Akemo i wsp. 2000; Hauggard-Nielsen i wsp. 2001). Oddziaływanie biomasy roślinnej na właściwości gleby oraz plonowanie roślin zależy głównie od: jej rodzaju, składu chemicznego, terminu i sposobu umieszczenia w glebie (Kuś i Jończyk 2000; Jaskulski i Tomalak 2001). Z badań Hansena i wsp. (2000) wynika, że na plon zbóż jarych korzystniej wpływa przyoranie biomasy poplonowej przed zimą, niż pozostawienie jej w formie mulczu do wiosny.

Ryzyko występowania anomalii pogodowych w trakcie okresu wegetacyjnego oraz duży udział zbóż w strukturze zasiewów spowodowały, że podjęto próby znalezienia rozwiązań ułatwiających roślinom regenerację po wystąpieniu czynników stresowych (monokultura), a jednocześnie polepszających jakość i wielkość plonów. Według Słowińskiego (2008) i Kozaka (2009) mogą w tym pomóc biostymulatory, które coraz częściej stają się elementami agrotechniki wielu gatunków roślin uprawnych. Zdaniem producentów biostymulatorów ich stosowanie umożliwia lepsze wykorzystanie potencjału plonotwórczego roślin uprawnych oraz zwiększa dbałość o środowisko naturalne, zastępując częściowo chemiczne środki ochrony roślin. Słowiński (2004) oraz Maciejewski i wsp. (2007) uważają, że biopreparaty wspomagają naturalne procesy życiowe roślin, szczególnie w warunkach stresowych, co przyczynia się do uzyskania wyższych i lepszych jakościowo plonów.

Celem badań było poznanie reakcji pszenicy jarej na uprawę monokulturową, a także określenie wpływu międzyplonu ścierniskowego oraz czterech różnych biostymulatorów na zachwaszczenie i wielkość plonu pszenicy uprawianej w dwuletniej monokulturze. Hipoteza badawcza zakładała korzystny wpływ zabiegów regeneracyjnych na wzrost konkurencyjności rośliny uprawnej wobec chwastów i w efekcie wzrost plonu ziarna w krótkotrwałej uprawie pszenicy jarej po sobie.

\section{Materiały i metody / Materials and methods}

Dwa ścisłe doświadczenia polowe realizowane były w latach 2011 i 2012 na terenie Opolskiego Ośrodka Doradztwa Rolniczego w Łosiowie. Zostały założone metodą losowanych podbloków, w czterech powtórzeniach na poletkach wielkości $20 \mathrm{~m}^{2}$ na glebie brunatnej właściwej kompleksu pszennego dobrego o $\mathrm{pH}_{\mathrm{KCl}}=6,7$.

W eksperymencie jednoczynnikowym badano wpływ następstwa roślin (płodozmian: rzepak ozimy - pszenica jara - jęczmień ozimy oraz monokultura pszenicy) na zachwaszczenie i plonowanie pszenicy jarej. W doświadczeniu dwuczynnikowym, w którym pszenicę uprawiano bezpośrednio po sobie, określono wpływ biostymulatorów: Nano-Gro, Asahi SL, PRP EBV, Wuxal Ascofol i przyorywanego corocznie przed zimą międzyplonu ścierniskowego $\mathrm{z}$ facelii błękitnej na zachwaszczenie $\mathrm{i}$ produkcyjność pszenicy.

Skład biostymulatorów, zgodnie z informacjami producentów, przedstawiał się następująco:

Nano-Gro zawiera nano-stężenia kilku pierwiastków, tj.: Fe, Co, Al, Mg, Mn, Ni i Ag występujących w formie siarczanów, zamkniętych $\mathrm{w}$ granulce $\mathrm{z}$ oligosacharydów czyszczonych alkoholem etylowym. Asahi SL zawiera trzy substancje czynne z grupy nitrofenoli: orto-nitrofenol sodu, para-nitrofenol sodu oraz 5-nitroguajakol sodu. PRP EBV jest płynnym nawozem potasowo-magnezowo-sodowym $\mathrm{z}$ dodatkiem miedzi. Wuxal Ascofol to nawóz zawierający wyciąg $\mathrm{z}$ alg morskich Ascophyllum nodosum, bogaty w mikroelementy (m.in.: B, Mn, $\mathrm{Zn}, \mathrm{Fe}$ i $\mathrm{Mg}$ ), naturalne hormony wzrostu oraz witaminy i kwasy organiczne.

Pod pszenicę jarą zastosowano nawożenie mineralne dostosowane do zaleceń agrotechnicznych oraz przebiegu pogody i kondycji rośliny uprawnej - $120 \mathrm{~kg} \mathrm{~N} / \mathrm{ha}$ w pierwszym roku badań i $80 \mathrm{~kg} \mathrm{~N} / \mathrm{ha} \mathrm{w}$ drugim roku. Nie stosowano natomiast nawożenia fosforem i potasem ze względu na wysoką zasobność gleby w te pierwiastki.

$\mathrm{Na}$ wszystkich poletkach doświadczenia w fazie krzewienia pszenicy (BBCH 28) zastosowano herbicydy. W pierwszym roku badań był to Granstar 75 WG (tribenuron metylowy) + Starane 250 EC (fluroksypyr) w dawce $15 \mathrm{~g}+0,3 \mathrm{l}$, natomiast w drugim - Granstar Ultra SX 50 SG (tribenuron metylowy + tifensulfuron metylowy) $\mathrm{z}$ adiuwantem Trend 90 EC (etoksylowany alkohol inadocylowy) w ilości $48 \mathrm{~g}+0,05 \%$. Zabiegi zwalczania chorób grzybowych przeprowadzono preparatami: Capalo 337,5 EC (fenpropimorf + metrafenon + epoksykonazol) w ilości 1,5 1/ha w roku 2011 oraz Input 460 EC (spiroksamina + protikonazol) + Fandango 200 EC (protikonazol + fluoksastrobina) w dawkach $0,5 \mathrm{l} / \mathrm{ha}$ w roku 2012. Ponadto w drugim roku badań na szkodniki zastosowano Karate Zeon 050 SC (lambda-cyhalotryna) w ilości 0,12 1/ha. Środki ochrony roślin aplikowano przy użyciu opryskiwacza polowego Pilmet o ciśnieniu 0,35 MPa i wydatku cieczy roboczej 200 l/ha.

W okresie wegetacji pszenicy jarej średnie temperatury powietrza zarówno w roku 2011, jak i 2012, przekraczały średnią wieloletnią, odpowiednio o 1,2 i $0,7^{\circ} \mathrm{C}$. Najcieplejszymi miesiącami w pierwszym roku badań były czerwiec i sierpień, natomiast $\mathrm{w}$ drugim roku lipiec i sierpień. Suma opadów w 2011 roku przewyższała wartości średnie $w$ rejonie o $83,6 \mathrm{~mm}$. Negatywnie na rozwój pszenicy jarej wpłynęły obfite opady śniegu oraz przymrozki w początku maja. Szczególnie dużo deszczu spadło w końcu czerwca. Suma opadów w drugim roku była zbliżona do sumy opadów wielolecia. 
Ocenę stopnia zachwaszczenia łanu przeprowadzono w dwóch terminach: wiosną bezpośrednio przed chemicznym zabiegiem odchwaszczania (BBCH 27$)$ na powierzchni $0,2 \mathrm{~m}^{2}$ i przed zbiorem pszenicy (BBCH 92) na powierzchni $0,5 \mathrm{~m}^{2}$. Badania obejmowały liczebność i skład gatunkowy chwastów, a w przypadku drugiego terminu także oznaczenie powietrznie suchej masy chwastów. Zbiór pszenicy jarej przeprowadzono w fazie dojrzałości pełnej, a następnie określono plon ziarna przy wilgotności $15 \%$. Wyniki dwuletnich badań poddano analizie wariancji, a istotność różnic między średnimi oceniano testem t-Studenta na poziomie $\alpha=0,05$.

\section{Wyniki i dyskusja / Results and discussion}

Uprawa pszenicy jarej w monokulturze, w porównaniu $\mathrm{z}$ uprawą w płodozmianie rzepak ozimy - pszenica jara jęczmień ozimy, przyczyniła się do istotnego wzrostu zachwaszczenia pierwotnego (rys. 1). Podobną zależność zaobserwowała Głowacka (2006), która w dwuletniej uprawie pszenicy jarej po sobie stwierdziła 5,4\% wzrost zachwaszczenia w porównaniu z płodozmianem kukurydza - fasola zwyczajna - pszenica jara. W badaniach własnych wpływ następstwa roślin na zachwaszczenie istotnie zaznaczył się już w fazie krzewienia pszenicy jarej. W tym okresie w 2-letniej monokulturze liczba chwastów była wyższa niż w płodozmianie o 49,7\%. Adamiak i Adamiak (2004) podobną zależność zaobserwowali w wieloletniej monokulturze owsa, gdzie liczba chwastów była 3-krotnie większa niż w 6-polowym płodozmianie (ziemniak owies - len włóknisty - żyto ozime - bobik - pszenżyto ozime). Przed zbiorem rośliny uprawnej zarówno w płodozmianie, jak i monokulturze, zachwaszczenie zmniejszyło się w stosunku do obsady chwastów oznaczonej wiosną, średnio o $80 \%$. W terminie zbioru pszenicy jarej uprawianej po sobie zaobserwowano 1,5 razy więcej chwastów w porównaniu z płodozmianem, jednak zależności tej nie potwierdzono statystycznie.
Ocena zachwaszczenia $\mathrm{w}$ terminie zbioru pszenicy wykazała, że uprawa pszenicy po sobie przyczyniła się do 2,8-krotnego zwiększenia suchej masy chwastów w porównaniu z płodozmianem (rys. 1). Także Głowacka (2006) udowodniła niekorzystny wpływ dwuletniej monokultury pszenicy jarej przez zwiększenie powietrznie suchej masy o 22,6\%. Kwiatkowski i wsp. (2004) w monokulturze jęczmienia jarego stwierdzili aż 120\% wzrost suchej masy chwastów $\mathrm{W}$ porównaniu $\mathrm{z}$ płodozmianem ziemniak $^{++}$ jęczmień jary - mieszanka zbożowo-strączkowa.

Wprowadzenie do monokultury pszenicy jarej zabiegów o charakterze regeneracyjnym wykazało ich zróżnicowaną skuteczność (tab. 1). Uprawa międzyplonu ścierniskowego $\mathrm{z}$ facelii błękitnej w charakterze przerywnika fitosanitarnego i nawozowego nie wpłynęła istotnie na redukcję liczby chwastów w łanie. Natomiast Gawęda (2009) po przyoraniu międzyplonu z gorczycy białej w monokulturze pszenicy jarej stwierdziła redukcję liczby chwastów $\mathrm{w}$ porównaniu $\mathrm{z}$ zanotowaną po międzyplonie z facelii błękitnej i z obiektu kontrolnego bez międzyplonu, odpowiednio o 65,1 i 55,7\%. Z kolei Woźniak (2005) przyorując wsiewkę $\mathrm{z}$ życicy westerwoldzkiej w monokulturze pszenicy jarej zauważył prawie 2-krotny wzrost zachwaszczenia łanu w stosunku do poletek, na których przyorywano wsiewkę z seradeli i obornik oraz 5-krotny w porównaniu ze zmianowaniem typu norfolskiego.

Wykorzystanie biostymulatorów jako czynnika regeneracyjnego przyczyniło się do wzrostu liczebności chwastów pszenicy jarej uprawianej po sobie w obu terminach badań. Należy jednak zaznaczyć, że istotny wzrost zachwaszczenia $\mathrm{W}$ porównaniu $\mathrm{z}$ monokulturą bez biostymulatorów zaobserwowano tylko w terminie zbioru pszenicy jarej i najsilniej zaznaczył się on po aplikacji preparatu Asahi SL (o 86\%) oraz Nano-Gro (o 59\%). Natomiast Jabłońska i wsp. (2012) po zastosowaniu biopreparatów EM-Farming i Biojodis w uprawie pszenżyta jarego odnotowali niepotwierdzony statystycznie wzrost zachwaszczenia łanu w stosunku do pszenżyta, w którym nie zastosowano biopreparatów.

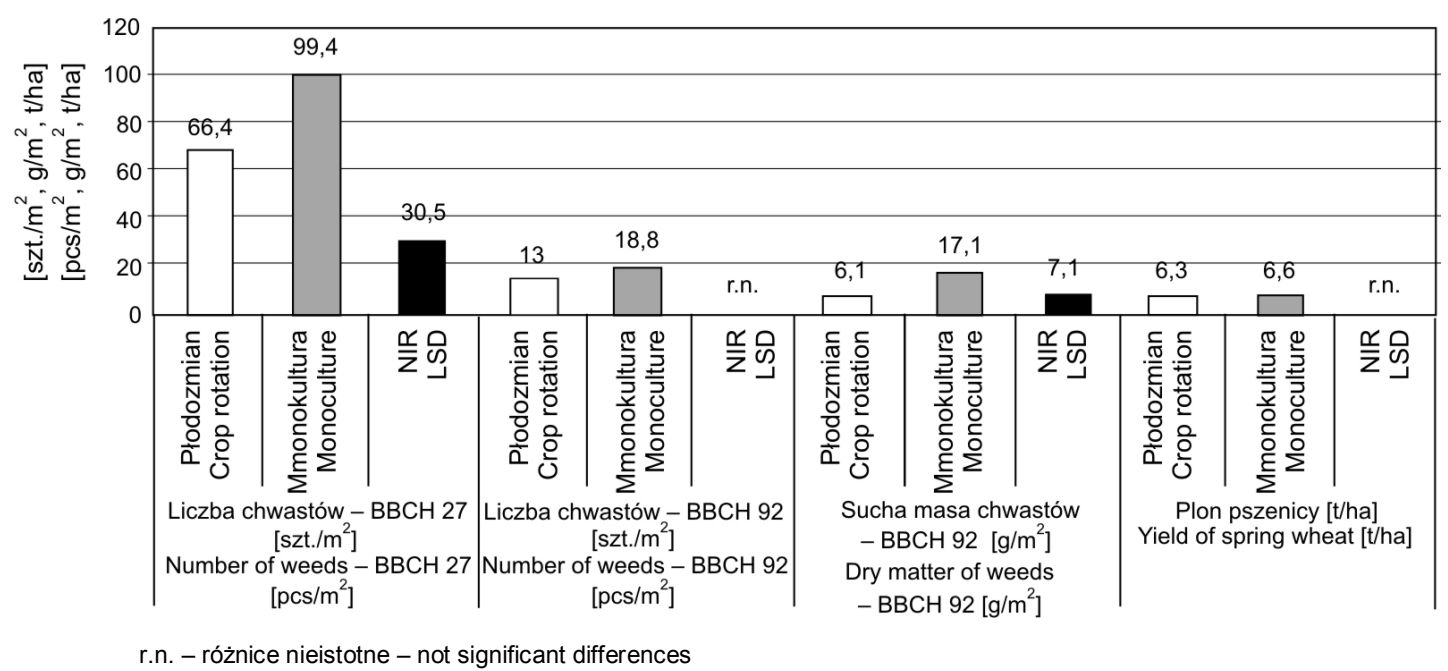

Rys. 1. Wpływ następstwa roślin na zachwaszczenie i plonowanie pszenicy jarej

Fig. 1. The effect of plant succession on weed infestation and yield of spring wheat 
Tabela 1. Wpływ zabiegów regeneracyjnych na liczbę chwastów w monokulturowej uprawie pszenicy jarej

Table 1. Influence of regeneration practices on the number of weeds in continuous cropping of spring wheat

\begin{tabular}{|c|c|c|c|c|c|c|}
\hline \multirow{4}{*}{$\begin{array}{l}\text { Biostymulator } \\
\text { Biostymulant }\end{array}$} & \multicolumn{3}{|c|}{ Krzewienie - Tillering } & \multicolumn{3}{|c|}{ Przed zbiorem - Before harvest } \\
\hline & \multicolumn{2}{|c|}{ monokultura - monoculture } & \multirow[b]{2}{*}{$\begin{array}{l}\text { średnio } \\
\text { mean }\end{array}$} & \multicolumn{2}{|c|}{ monokultura - monoculture } & \multirow[b]{2}{*}{$\begin{array}{l}\text { średnio } \\
\text { mean }\end{array}$} \\
\hline & $\begin{array}{l}\text { bez międzyplonu } \\
\text { without stubble } \\
\text { crop }\end{array}$ & $\begin{array}{l}\text { z międzyplonem } \\
\text { with stubble crop }\end{array}$ & & $\begin{array}{c}\text { bez międzyplonu } \\
\text { without stubble crop }\end{array}$ & $\begin{array}{l}\text { z międzyplonem } \\
\text { with stubble crop }\end{array}$ & \\
\hline & \multicolumn{6}{|c|}{$\left[\mathrm{szt} . / \mathrm{m}^{2}-\mathrm{pcs} / \mathrm{m}^{2}\right]$} \\
\hline Brak - Without & 99,4 & 73,1 & 86,3 & 18,8 & 10,3 & 14,5 \\
\hline Nano-Gro & 105,6 & 85,0 & 95,3 & 21,8 & 24,5 & 23,1 \\
\hline Asahi SL & 131,3 & 106,9 & 119,1 & 32,8 & 21,3 & 27,0 \\
\hline PRP EBV & 138,1 & 91,9 & 115,0 & 21,0 & 12,8 & 16,9 \\
\hline Wuxal Ascofol & 129,4 & 108,1 & 118,8 & 21,6 & 19,0 & 20,3 \\
\hline Średnio - Mean & 120,8 & 93,0 & - & 23,2 & 17,6 & - \\
\hline $\begin{array}{l}\text { NIR }(0,05) \text { dla międzyplonu } \\
\operatorname{LSD}(0.05) \text { for stubble crop }\end{array}$ & \multicolumn{3}{|c|}{ r.n. } & \multicolumn{3}{|c|}{ r.n. } \\
\hline $\begin{array}{l}\text { NIR }(0,05) \text { dla biostymulatora } \\
\text { LSD }(0.05) \text { for biostymulants }\end{array}$ & \multicolumn{3}{|c|}{ r.n. } & \multicolumn{3}{|c|}{7,8} \\
\hline $\begin{array}{l}\text { NIR }(0,05) \text { dla interakcji } \\
\text { LSD }(0.05) \text { for interaction }\end{array}$ & \multicolumn{3}{|c|}{ r.n. } & \multicolumn{3}{|c|}{ r.n. } \\
\hline
\end{tabular}

r.n. - różnice nieistotne - not significant differences

Tabela 2. Wpływ zabiegów regeneracyjnych na powietrznie suchą masę chwastów przed zbiorem pszenicy jarej

Table 2. The influence of regeneration practices on the dry weight of weeds before spring wheat harvest

\begin{tabular}{|c|c|c|c|}
\hline \multirow{3}{*}{$\begin{array}{l}\text { Biostymulator } \\
\text { Biostymulant }\end{array}$} & \multicolumn{2}{|c|}{ Monokultura - Monoculture } & \multirow{2}{*}{$\begin{array}{l}\text { Średnio } \\
\text { Mean }\end{array}$} \\
\hline & $\begin{array}{c}\text { bez międzyplonu } \\
\text { without stubble crop }\end{array}$ & $\begin{array}{l}\text { z międzyplonem } \\
\text { with stubble crop }\end{array}$ & \\
\hline & \multicolumn{3}{|c|}{$\left[\mathrm{g} / \mathrm{m}^{2}\right]$} \\
\hline Brak - Without & 17,1 & 13,9 & 15,5 \\
\hline Nano-Gro & 20,5 & 18,0 & 19,3 \\
\hline Asahi SL & 27,5 & 15,7 & 21,6 \\
\hline PRP EBV & 25,5 & 8,7 & 17,1 \\
\hline Wuxal Ascofol & 20,9 & 13,4 & 17,1 \\
\hline Średnio - Mean & 22,3 & 13,9 & - \\
\hline $\begin{array}{l}\text { NIR }(0,05) \text { dla międzyplonu } \\
\text { LSD }(0.05) \text { for stubble crop }\end{array}$ & \multicolumn{3}{|c|}{4,3} \\
\hline $\begin{array}{l}\text { NIR }(0,05) \text { dla biostymulatora } \\
\text { LSD }(0.05) \text { for biostymulants }\end{array}$ & \multicolumn{3}{|c|}{ r.n. } \\
\hline $\begin{array}{l}\text { NIR }(0,05) \text { dla interakcji } \\
\operatorname{LSD}(0.05) \text { for interaction }\end{array}$ & \multicolumn{3}{|c|}{ r.n. } \\
\hline
\end{tabular}

r.n. - różnice nieistotne - not significant differences

Wykorzystanie międzyplonu ścierniskowego na przyoranie w agrotechnice powtarzanej uprawy pszenicy jarej sprzyjało istotnemu ograniczeniu masy chwastów (o 37,7\%) w odniesieniu do pszenicy, przed którą nie uprawiano międzyplonu (tab. 2). W badaniach Gawędy (2009) wprowadzenie do uprawy pszenicy jarej facelii błękitnej ograniczało powietrznie suchą masę chwastów aż o $68,9 \%$ w stosunku do stwierdzonej w stanowisku bez międzyplonu. Z kolei Parylak (1997) uprawiając w monokulturze pszenżyta ozimego międzyplon ścierniskowy zaobserwowała zmniejszenie suchej masy chwastów o 25\% w stosunku do pszenżyta uprawianego bezpośrednio po sobie. Użycie biostymulatorów w monokulturowej uprawie pszenicy jarej skutkowało nieistotnym zwiększeniem powietrznie suchej masy chwastów. Największy przyrost biomasy w stosunku do odnotowanej na poletkach bez biostymulatora stwierdzono po aplikacji Asahi SL (28,2\%) i Nano-Gro (o 19,9\%).

W sezonie wegetacyjnym większą różnorodnością gatunkową charakteryzowała się krótkotrwała monokultura, w której wystąpiło 17 gatunków chwastów, w przeciwieństwie do płodozmianu, gdzie zaobserwowano 
Tabela 3. Skład gatunkowy i liczba chwastów w uprawie pszenicy jarej [szt. $\left./ \mathrm{m}^{2}\right]$

Table 3. Weed species and their abundance in the spring wheat canopy $\left[\mathrm{pcs} / \mathrm{m}^{2}\right]$

\begin{tabular}{|c|c|c|c|c|}
\hline \multirow{2}{*}{$\begin{array}{l}\text { Skład gatunkowy } \\
\text { Species composition }\end{array}$} & \multicolumn{2}{|c|}{ Krzewienie - Tillering } & \multicolumn{2}{|c|}{ Przed zbiorem - Before harvest } \\
\hline & $\begin{array}{l}\text { płodozmian } \\
\text { crop rotation }\end{array}$ & $\begin{array}{l}\text { monokultura } \\
\text { monoculture }\end{array}$ & $\begin{array}{l}\text { płodozmian } \\
\text { crop rotation }\end{array}$ & $\begin{array}{l}\text { monokultura } \\
\text { monoculture }\end{array}$ \\
\hline Jasnota purpurowa - Lamium purpureum $\mathrm{L}$. & 40 & 39,4 & - & $<0,1$ \\
\hline Fiołek polny - Viola arvensis Murr. & 21,5 & 49,3 & 2,5 & 2,3 \\
\hline Przytulia czepna - Galium aparine L. & 0,5 & 6,9 & - & 5,4 \\
\hline Rzepak - Brassica napus var. oleifera L. & - & 6,2 & - & 0,4 \\
\hline Komosa biała - Chenopodium album $\mathrm{L}$. & - & 14,4 & - & $<0,1$ \\
\hline Gwiazdnica pospolita - Stellaria media L. Vill. & - & - & 5 & 6,6 \\
\hline Chwastnica jednostronna - Echinochloa crus-galli L. & - & 8,3 & - & - \\
\hline Tobołki polne - Thlaspi arvense L. & - & 3,4 & - & $<0,1$ \\
\hline Żółtlica drobnokwiatowa - Galinsoga parviflora Cav. & - & 3 & - & 0,7 \\
\hline Ostrożeń polny - Cirsium arvense L. Scop. & - & 2 & - & $<0,1$ \\
\hline Przymiotno kanadyjskie - Conyza canadensis L. & - & 1,2 & - & - \\
\hline Bodziszek - Geranium sp. & - & 1,8 & - & - \\
\hline Dymnica pospolita - Fumaria officinalis L. & - & 1,0 & - & - \\
\hline Przetacznik bluszczykowy - Veronica hederifolia L. & - & 0,3 & - & $<0,1$ \\
\hline Poziewnik szorstki - Galeopsis tetrahit L. & - & - & - & 0,4 \\
\hline Gorczyca polna - Sinapis arvensis L. & - & - & - & $<0,1$ \\
\hline Jaskier polny - Ranunculus arvensis L. & - & - & - & $<0,1$ \\
\hline Ogółem - Total & 67 & 137,2 & 7,5 & 16,5 \\
\hline
\end{tabular}

Tabela 4. Wpływ międzyplonu i biostymulatorów na plonowanie pszenicy jarej uprawianej w monokulturze

Table 4. The effect of stubble crop and biostimulants on yield of spring wheat cultivated in monoculture

\begin{tabular}{|c|c|c|c|}
\hline \multirow{3}{*}{$\begin{array}{l}\text { Biostymulator } \\
\text { Biostimulant }\end{array}$} & \multicolumn{2}{|c|}{ Monokultura - Monoculture } & \multirow{2}{*}{$\begin{array}{c}\text { Średnio } \\
\text { Mean }\end{array}$} \\
\hline & $\begin{array}{l}\text { bez międzyplonu } \\
\text { without stubble crop }\end{array}$ & $\begin{array}{l}\text { z międzyplonem } \\
\text { with stubble crop }\end{array}$ & \\
\hline & \multicolumn{3}{|c|}{$[\mathrm{t} / \mathrm{ha}]$} \\
\hline Brak - Without & 6,6 & 6,4 & 6,5 \\
\hline Nano-Gro & 6,8 & 6,7 & 6,7 \\
\hline Asahi SL & 6,8 & 6,7 & 6,7 \\
\hline PRP EBV & 7,1 & 6,6 & 6,9 \\
\hline Wuxal Ascofol & 6,7 & 6,9 & 6,8 \\
\hline Średnio - Mean & 6,8 & 6,7 & - \\
\hline $\begin{array}{l}\text { NIR }(0,05) \text { dla międzyplonu } \\
\text { LSD }(0.05) \text { for stubble crop }\end{array}$ & \multicolumn{3}{|c|}{ r.n. } \\
\hline $\begin{array}{l}\text { NIR }(0,05) \text { dla biostymulatora } \\
\text { LSD }(0.05) \text { for biostymulants }\end{array}$ & \multicolumn{3}{|c|}{ r.n. } \\
\hline $\begin{array}{l}\text { NIR }(0,05) \text { dla interakcji } \\
\operatorname{LSD}(0.05) \text { for interaction }\end{array}$ & \multicolumn{3}{|c|}{ r.n. } \\
\hline
\end{tabular}

r.n. - różnice nieistotne - not significant differences

jedynie 5 gatunków (tab. 3). W fazie krzewienia zarówno w płodozmianie, jak i monokulturze zdecydowanie dominowały Lamium purpureum oraz Viola arvensis. W mniejszych ilościach występowały również: Chenopodium album, Echinochloa crus-galli, Galium aparine, Brassica napus var. oleifera, Thlaspi arvense. Przed zbiorem pszenicy jarej istotną rolę $\mathrm{w}$ zachwaszczeniu łanu odgrywały Stellaria media, $V$. arvensis oraz dodatkowo w uprawie powtarzanej $G$. aparine. W badaniach Gawędy (2009) gatunkiem dominującym w monokulturze pszenicy jarej było $C h$. album, licznie występowały również: $S$. media, E. crus-galli, Sonchus asper, Amarantus retroflexus oraz Sonchus oleraceus. Kwiatkowski i wsp. (2004) do gatunków dominujących pod względem liczebności w up- 
rawie jęczmienia jarego w płodozmianie i 7-letniej monokulturze zaliczyli: Matricaria maritima ssp. indora, E. crus-galli, S. media, V. arvensis i Agropyron repens.

Zarówno następstwo roślin, jak i zabiegi regeneracyjne nie modyfikowały istotnie plonu ziarna pszenicy jarej w 2-krotnej uprawie po sobie, prawdopodobnie $\mathrm{z}$ powodu krótkotrwałej uprawy pszenicy po sobie w korzystnych warunkach siedliskowych (tab. 4). Zdaniem wielu autorów konsekwencją uprawy pszenicy w monokulturze jest spadek plonu ziarna oraz pogorszenie jego jakości technologicznej. Woźniak i wsp. (2006) w monokulturze pszenicy jarej zaobserwowali plon niższy o 24,7-32,4\% w stosunku do zmianowań z 25-75\% udziałem pszenicy w strukturze zasiewów. Główną przyczyną tej obniżki była mniejsza obsada kłosów na $1 \mathrm{~m}^{2}$, masa ziarna $\mathrm{z}$ kłosa oraz masa 1000 ziaren. Również wcześniejsze badania Woźniaka (2003) wykazały 36\% redukcję plonu pszenicy jarej uprawianej $\mathrm{w}$ monokulturze $\mathrm{w}$ stosunku do zmianowań z 25 i 50\% udziałem pszenicy jarej.

Zastosowanie międzyplonu ścierniskowego w postaci facelii błękitnej spowodowało nieznaczny spadek plonu ziarna pszenicy jarej uprawianej w monokulturze w porównaniu $\mathrm{z}$ uprawą pszenicy bezpośrednio po sobie (tab. 4). Niekorzystny wpływ międzyplonu ścierniskowego na wysokość plonu pszenicy prawdopodobnie był związany $\mathrm{z}$ mniejszą obsadą kłosów na $1 \mathrm{~m}^{2}$. Zmniejszenie plonu pszenicy jarej uprawianej po gorczycy białej lub facelii błękitnej w porównaniu do międzyplonu z mieszanki roślin strączkowych odnotowali Gawęda i Kwiatkowski (2012) i wynosił on odpowiednio 6,5 i 5,4\%. Odmienne zdanie mają Kuś i Jończyk (2000) oraz Harasim i Gawęda (2010), którzy w swoich badaniach wykazali korzystny wpływ międzyplonów na plonowanie zbóż jarych. Wszystkie zastosowane preparaty biostymulujące spowodowały nieistotny statystycznie wzrost plonu ziarna pszenicy jarej.

\section{Wnioski / Conclusions}

1. Uprawa pszenicy jarej w krótkotrwałej monokulturze, w stosunku do uprawy w płodozmianie rzepak ozimy pszenica jara - jęczmień ozimy, spowodowała istotny wzrost liczby chwastów w fazie krzewienia oraz zwiększenie ich masy przed zbiorem.

2. Coroczne przyorywanie międzyplonu ścierniskowego z facelii błękitnej w monokulturze pszenicy jarej sprzyjało istotnemu ograniczeniu masy chwastów.

3. Stosowanie biostymulatorów w 2-letniej monokulturze okazało się nieskuteczne $\mathrm{w}$ redukcji zachwaszczenia łanu pszenicy jarej, a aplikacja Asahi SL oraz NanoGro przyczyniła się do wyraźnego wzrostu liczby chwastów.

4. Niezależnie od następstwa roślin oraz zastosowanego czynnika regeneracyjnego dominującymi gatunkami chwastów w dwuletniej monokulturze pszenicy jarej były: L. purpureum, $V$. arvensis oraz $S$. media. W mniejszych ilościach występowały: Ch. album, E. crus-galli, G. aparine, B. napus var. oleifera, T. arvense.

5. Zarówno następstwo roślin, jak i zabiegi regeneracyjne $\mathrm{w}$ monokulturowej uprawie pszenicy nie miały znaczącego wpływu na plonowanie roślin.

\section{Literatura / References}

Adamiak E., Adamiak J. 2004. Zachwaszczenie owsa w warunkach zróżnicowanego następstwa roślin i chemicznej ochrony łanu. Acta Scientiarum Polonorum Agricultura 3 (1): 119-128.

Akemo M., Regnier E., Bennet M. 2000. Weed suppresion in spring-sown rye (Secale cereale) - Pea (Pisum sativum) cover crop mixes. Weed Technology 14: 545-549.

Gawęda D. 2009. Wpływ międzyplonów ścierniskowych na zachwaszczenie pszenicy jarej uprawianej w monokulturze. Annales Universitatis Mariae Curie-Skłodowska, Sectio E, Agricultura 64 (3): 21-28.

Gawęda D., Kwiatkowski C.A. 2012. Plonowanie pszenicy jarej uprawianej w krótkotrwałej monokulturze w zależności od międzyplonu i sposobu odchwaszczania. Annales Universitatis Mariae Curie-Skłodowska, Sectio E, Agricultura 67 (2): $50-58$.

Głowacka A. 2006. Wpływ monokultury, płodozmianu i uprawy współrzędnej na bioróżnorodność chwastów w pszenicy jarej. Acta Agrophysica 8 (3): 569-577.

Haliniarz M. 2010. Wpływ gęstości łanu na dynamikę przyrostu biomasy pszenicy jarej i chwastów. Annales Universitatis Mariae Curie-Skłodowska, Sectio E, Agricultura 65 (2): 68-79.

Hansen E.M., Kristensen K., Djurhuus J. 2000. Yield parameters as affected by introduction or discontinuation of catch crop use. Agronomy Journal 92: 909-914.

Harasim E., Gawęda D. 2010. Wpływ międzyplonów ścierniskowych na plonowanie i efektywność energetyczną produkcji zbóż jarych. Annales Universitatis Mariae Curie-Skłodowska, Sectio E, Agricultura 65 (1): 64-72.

Hauggaard-Nielsen H., Ambus P., Jensen E.S. 2001. Interspecific competition, N use and interference with weeds in pea-barley intercropping. Field Crops Research 70: 101-109.

Jabłońska M., Giemza-Mikoda M., Lehmann A., Paluch M. 2012. Wpływ systemów uprawy roli oraz wybranych biopreparatów na zachwaszczenie łanu pszenżyta jarego uprawianego w krótkotrwałej monokulturze. Episteme 15: 89-95.

Jaskulski D., Tomalak S. 2001. Wpływ głębokości i sposobu umieszczenia biomasy różnych gatunków roślin w glebie na wschody i masę siewki jęczmienia jarego. Zeszyty Naukowe, Akademia Techniczno-Rolnicza w Bydgoszczy, Rolnictwo 47: 7-14.

Jaskulski D., Tomalak S., Rudnicki F. 2000. Regeneracja stanowiska po pszenicy ozimej dla jęczmienia jarego przez rośliny międzyplonu ścierniskowego. Zeszyty Problemowe Postępów Nauk Rolniczych 470: 49-57.

Kozak M. 2009. Biostymulator dobry wybór. Agrotechnika, Warszawa 3: 61-62.

Kuś J., Jończyk K. 2000. Regenerująca rola międzyplonów w zbożowych członach zmianowania. Zeszyty Problemowe Postępów Nauk Rolniczych 470: 59-65. 
Kwiatkowski C., Wesołowski M., Stępień A. 2004. Bioróżnorodność chwastów w trzech odmianach jęczmienia jarego uprawianych w siedmioletniej monokulturze i zmianowaniu. Acta Scientiarum Polonorum Agricultura 3 (2): 109-117.

Maciejewski T., Szukała J., Jarosz A. 2007. Wpływ biostymulatora Asahi SL i Atonik SL na cechy jakościowe bulw ziemniaka. Journal of Research and Applications in Agricultural Engineering 52 (3): 109-112.

Parylak D. 1997. Zachwaszczenie pszenżyta ozimego w narastającej monokulturze. Zeszyty Naukowe Akademii Rolniczej w Szczecinie 175, Rolnictwo 65: 299-305.

Parylak D. 1998. Optymalizacja uprawy pszenżyta ozimego w krótkotrwałej monokulturze na glebie kompleksu żytniego dobrego. Zeszyty Naukowe Akademii Rolniczej we Wrocławiu 326, Rozprawy 150: 7-94.

Słowiński A. 2004. Biostymulatory w nowoczesnej uprawie roślin. Wieś Jutra 3 (68): 25-26.

Słowiński A. 2008. Biostymulatory w polowej produkcji roślinnej. Wieś Jutra 5 (118): 29-30.

Teasdale J.R., Beste C.E., Potts W.E. 1991. Response of weeds to tillage and cover crop residue. Weed Science 39: 195-199.

Wojciechowski W. 1998. Międzyplony ścierniskowe jako czynnik zapobiegający negatywnym skutkom wysycenia struktury zasiewów zbożami. Postępy Nauk Rolniczych 5: 29-36.

Woźniak A. 2003. Wpływ zróżnicowanego udziału pszenicy jarej w zmianowaniu na plon i jakość ziarna. Biuletyn Instytutu Hodowli i Aklimatyzacji Roślin 228: 41-50.

Woźniak A. 2005. Wpływ wsiewek międzyplonowych i nawożenia organicznego na plonowanie i zachwaszczenie pszenicy jarej uprawianej w monokulturze. Annales Universitatis Mariae Curie-Skłodowska, Sectio E, Agricultura 60: 33-40.

Woźniak A., Gontarz D., Staniszewski M., Gos M. 2006. Plonowanie i jakość ziarna pszenicy jarej uprawianej w zmianowaniach o różnym jej udziale. Biuletyn Instytutu Hodowli i Aklimatyzacji Roślin 242: 45-55. 